\title{
Self-Medication Practice and Associated Factors Among Teachers' Education Training College Students in Amhara Region, Ethiopia: A Cross- Sectional Study
}

\author{
Abebe Basazn Mekuria ( $\square$ abeyohannes21@gmail.com ) \\ Lecturer https://orcid.org/0000-0003-2909-2001

\section{Eshetie Melese Birru} \\ University of Gondar College of Medicine and Health Sciences \\ Melkamu Teshome Tesfa \\ University of Gondar College of Medicine and Health Sciences \\ Mestayet Geta \\ University of Gondar College of Medicine and Health Sciences

\section{Tsegaw Amare Bykeda} \\ University of Gondar College of Medicine and Health Sciences
}

\section{Research article}

Keywords: Practice, Self-medication, Gondar, Student, Ethiopia

Posted Date: May 22nd, 2020

DOI: https://doi.org/10.21203/rs.3.rs-30132/v1

License: (c) (i) This work is licensed under a Creative Commons Attribution 4.0 International License.

Read Full License 


\section{Abstract}

Background Self-medication practice is the use of medications without health care professional request. It leads to irrational medication usage, wastage of resources, increased chance of microbial resistance and adverse drug reaction. Therefore, this study aimed at assessing the prevalence associated factors of self-medication practice among students teacher's education training college students in Amhara region, Ethiopia.

Methods A multicentre cross-sectional study was conducted on 344 teacher's education training college students in Amhara region, from January 1 to February 28, 2020. Systematic random sampling was used to select participants and data collected through structured questionnaire. Descriptive statistics, univariate and multivariate logistic regression analysis were done to determine various variables and factors associated with self-medication practice.

Results Out of 344 respondents, $68.0 \%$ were practiced self- medication. The most commonly cited indication for self-medication practice was headache 75 (32.05\%) followed by abdominal discomfort 53 (22.6\%). The respondents with age of greater than 26 years (AOR: 2.47, 95\% Cl: 1.18-3.94), third years of study (AOR: 3.14, 95\% Cl: 1.94-5.79), urban residence (AOR: 2.97, 95\% Cl: 1.06-3.64), near accessibility of pharmacy (AOR: $2.12,95 \% \mathrm{Cl}$ : 1.43-4.46) and who had peer/family pressure (AOR: $2.34,95 \% \mathrm{Cl}$ : $1.53-$ 3.56) were significantly associated with self-medication practice.

Conclusion More than two-thirds of the study participants practiced self-medication. Being from the urban area, having access to private pharmacy and increase year of study are positively affects the selfmedication practice.

\section{Introduction}

According to world health organization (WHO) definition, self-medication is the selection and use of medicines to treat self-recognized illnesses or symptoms (1). Inappropriate self-medication practice results in wastage of resources, increase the chance of drugs resistance and cause serious health problems such as adverse drug reactions, treatment failure, misuse of medications and drug dependence (2). Despite to this it may be reduce health cost and save the time spent waiting to see doctors for minor health problems $(3,4)$.

Currently, self-medication is becoming the worldwide public health problem. The prevalence of selfmedication has sharply increased throughout the world. The study report showed that up to $80 \%$ of drugs in developing countries were purchased without prescription $(5,6)$. The study conducted in Iran showed that $76 \%$ of individuals had the history of self-medication practice $(3,6)$. Studies showed that most of university and college of students were practice self-medication for example in Serbia (7), Nagara (8) and South India (9) $79.9 \%, 92.4 \%$ and $78.6 \%$ of students, respectively, practiced self-medications. Despite the increased practice of self-medication among students all over the world, majority of them are unaware of the harmfulness of self-medications $(3,5,8)$. 
Many studies reported that the factors associated with self-medication practice such as being youth age (10), low level of education, previous experience of self-medication, lack of time to visit physicians, low income $(11,12)$, urban residence, greater availability of medicinal product, media exposure, urgency of the problem, their health problems were considered as too trivial, non-availability of transport, ability to self-manage the symptoms, and increase of pharmaceuticals advertisement $(4,6)$. Accordingly, individuals were practice self-medications for different purpose. The studies report showed that headache, fever, cough (13), gastrointestinal diseases, respiratory tract infections, maternal/menstrual, eye diseases, skin diseases, injury and sexually transmitted diseases were the common indication of selfmedication practice $(8,10,14)$. To the best of our knowledge and search, there no study conducted in Ethiopia to explore prevalence and associated factors towards self-medication practice among students in teachers' education training college (TETC). Therefore, this study designed to assess the prevalence and factors associated with self-medication practice among TETC students in Amhara region, Ethiopia.

\section{Methods And Materials}

\section{Study design and area}

A multicenter cross-sectional study was conducted in TETC of Amhara region from January 1 to February 28,2020 . Amhara region is the second biggest administrative region in Ethiopia. This region has ten universities and seven teachers' education training colleges. Currently, 12,206 students are taking their training in Amhara region TETC. This study was approved by the ethical committee of the school of pharmacy, the University of Gondar with an approval number of SoP-318/2012. Informed verbal, as well as written consent was obtained from study participants prior to the data collection, and the purpose of the study was explained to the respondents in advance. The information collected from respondents was kept confidential.

\section{Sample Size Determination And Procedure}

The source population of the study was all students at Amhara region TETC, while a study population was those students who are studying at TETC during the data collection period. Regular undergraduate students who were available during the study period were included in the study, while students who were seriously ill and incapable of hearing and speaking during data collection were excluded. Single population proportion formula $(n=[(Z a / 2) 2 \times P(1-P)] /(D / 2))$ was applied with the assumption of $95 \%$ confidence interval, $5 \%$ margin of error, the prevalence $(p)$ of self-medication practice $(36.8 \%)(15)$ and $5 \%$ for possible non-response to determine a final sample size of 372 . The number of students to be interviewed in each college was calculated based proportion with the total number of students found in each college. Then, a systematic random sampling method was used to recruit the final study subjects.

\section{Data Collection Tools And Techniques}


Data collection was performed by three final year pharmacy students through a self-administered questionnaire. The questionnaire was developed after careful literature review of the published studies ( 2 , $8,10,12,14)$. First, it prepared in English and translated into the local language (Amharic) then back to the English language in order to ensure consistency. The tool was further pre-tested on 18 students who were not included in the final analysis and relevant modifications were performed before the commencement of the actual data collection. Completeness and fulfilment of all questions were checked by the principal investigator and data collectors. The final questionnaire was constituted 17 items that was divided into three main sections. The first section was focusing on the socio-demographic characteristics related information including age, gender, department, years of study, monthly income, residence, and parents' education level. The second section aimed to assess the prevalence of selfmedication practice, reasons for self-medication, medical conditions that promote self-medication, sources of supply and information for self-medication. The third section focused on the environmental characteristics of participants; include the distance of health institution, accessibility of pharmacy, presence of health professionals in the family, presence of medication at home, peer/family pressure.

\section{Statistical analysis}

The final collected data were checked for completeness, and responses were entered into and analysed using the Statistical Package for the Social Sciences (SPSS) software version 24.0 for Windows. Frequencies and percentages were used to express different variables, bi-variable followed by multivariable logistic regression analysis were used to determine factors associated with self-medication practice. Univariate analysis was done and variables with $p$-value less than 0.25 were further taken to the multivariate logistic regression analysis for proper adjustment with the possible confounders. In this study, adjusted odds ratio (AOR) at $95 \%$ confidence interval $(95 \% \mathrm{Cl})$ with $p$-value $(\mathrm{p}<0.05)$ considered as statistically significant.

\section{Results}

\section{Socio-demographic characteristics}

Out of 372 respondents invited to participate, 344 of them responded to the questions giving a response rate of $92.5 \%$. The mean age of respondents was 20.96 years with a standard deviation of \pm 2.40 and the half $175(50.9 \%)$ of respondents were female. Among respondents, $36.9 \%$ were in the third year of study. More than half of respondents (56.4\%) had 200-500 ETB monthly income. The majority of the respondents $(76.7 \%)$ came from rural areas. Regarding the study department, the most cited department was Art department $(24.7 \%)$ followed by science $(22.7 \%)$ and civics $(21.8 \%)$. The majority of the participants (52.1\%) were travelled more than one hour to reach health institutions, while $56.1 \%$ had access to pharmacies. The detail socio-demographic and self-medication related characteristics of respondents are summarized in Table 1. 
Table 1

Socio-demographic characteristics and associated factors with self-medication (SM) practice among TETC students, Amhara region, Ethiopia 2020 ( $\mathrm{N}=344)$.

\begin{tabular}{|c|c|c|c|c|}
\hline \multirow[t]{2}{*}{ Variable } & \multirow[t]{2}{*}{ Frequency (\%) } & \multicolumn{2}{|c|}{ SM practice } & \multirow[t]{2}{*}{ AOR (95\% Cl) } \\
\hline & & Yes(n) & No(n) & \\
\hline \multicolumn{5}{|l|}{ Age group in years } \\
\hline $16-20$ & $232(67.4)$ & 157 & 75 & 1 \\
\hline $21-25$ & $94(27.3)$ & 63 & 31 & $1.55(1.19-2.88) *$ \\
\hline$\geq 26$ & $18(5.3)$ & 14 & 4 & $2.47(1.18-3.94) *$ \\
\hline \multicolumn{5}{|l|}{ Sex } \\
\hline Male & $169(49.1)$ & 117 & 52 & 1 \\
\hline Female & $175(50.9)$ & 117 & 58 & $1.11(0.67-2.83)$ \\
\hline \multicolumn{5}{|l|}{ Year of study } \\
\hline 1st year & $98(28.5)$ & 60 & 38 & 1 \\
\hline 2nd year & $119(34.6)$ & 81 & 38 & $1.20\left(1.04-3.17^{*}\right.$ \\
\hline 3rd year & $127(36.9)$ & 93 & 34 & $3.14(1.94-5.79 *$ \\
\hline \multicolumn{5}{|l|}{ Residence } \\
\hline Rural & $80(23.3)$ & 61 & 19 & 1 \\
\hline Urban & $264(76.7)$ & 193 & 91 & $2.97(1.06-3.64) *$ \\
\hline \multicolumn{5}{|c|}{ Parents' educational level } \\
\hline Can't read and write & $138(40.1)$ & 94 & 44 & 1 \\
\hline NF education & $87(25.3)$ & 61 & 26 & $1.16(0.93-3.43)$ \\
\hline Grade 1-8 & $85(24.7)$ & 56 & 27 & $1.41(0.46-3.75)$ \\
\hline Grade $9-12$ & $18(5.2)$ & 11 & 7 & $1.47(1.46-3.21) *$ \\
\hline$\geq$ Diploma & $16(4.7)$ & 10 & 8 & $2.27(1.32-3.71) *$ \\
\hline \multicolumn{5}{|l|}{ Department } \\
\hline Amharic language & $16(4.7)$ & 9 & 7 & 1 \\
\hline English language & $44(12.8)$ & 26 & 18 & $1.14(0.65-2.42)$ \\
\hline $\begin{array}{l}\text { SM = Self-medication } \\
\text { = parents' education } \\
\text { (Biology, Physics, Ch } \\
\text { physical education), }\end{array}$ & $\begin{array}{l}\text { ormal, } \mathrm{HI}=\text { Healt } \\
\text { oove diploma; }{ }^{*} \text { s } \\
\text { * (Art generalist, } \\
\text { e }^{* \star * \star} \text { (Civics an }\end{array}$ & $\begin{array}{l}\text { itution, } \mathrm{H} \\
\text { cant at p- } \\
\text { c general } \\
\text { cs gener }\end{array}$ & $\begin{array}{l}\text { Health } \\
\text { ue }<0.0 \\
\text { special } \\
\text { t, Geogr }\end{array}$ & $\begin{array}{l}\text { fessional, } \geq \text { Diploma } \\
\text { latural science }{ }^{\star \star} \\
\text { eds, health and } \\
\text { y, History) }\end{array}$ \\
\hline
\end{tabular}




\begin{tabular}{|c|c|c|c|c|}
\hline \multirow[t]{2}{*}{ Variable } & \multirow[t]{2}{*}{ Frequency (\%) } & \multicolumn{2}{|c|}{ SM practice } & \multirow[t]{2}{*}{ AOR (95\% Cl) } \\
\hline & & Yes(n) & No(n) & \\
\hline Mathematics & $46(13.4$ & 20 & 26 & $1.97(0.56-2.79)$ \\
\hline Natural science** & 78 (22.7) & 36 & 42 & $1.21(0.47-2.24)$ \\
\hline 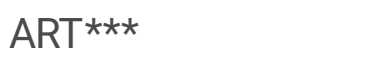 & $85(24.7)$ & 43 & 42 & $1.29(0.34-2.75)$ \\
\hline 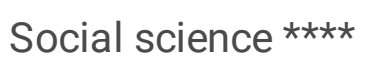 & 75 (21.8) & 52 & 23 & $1.85(0.67-2.92)$ \\
\hline \multicolumn{5}{|l|}{ Monthly income } \\
\hline$<200$ birr & $111(32.3)$ & 62 & 49 & 1 \\
\hline 200-500 birr & $134(56.4)$ & 74 & 60 & $1.22(0.47-2.45)$ \\
\hline$>500$ birr & 39 (11.3) & 21 & 18 & $1.65(0.66-3.45)$ \\
\hline \multicolumn{5}{|l|}{ The distance of HI } \\
\hline$<30 \min$ & 39 (11.3) & 18 & 21 & 1 \\
\hline 30 min -1 hour & $126(36.6)$ & 72 & 54 & $1.12(1.01-2.43) *$ \\
\hline$>1$ hour & $179(52.1)$ & 110 & 69 & $2.67(1.44-3.34) *$ \\
\hline \multicolumn{5}{|l|}{ Access to pharmacy } \\
\hline No & $193(56.1)$ & 77 & 74 & 1 \\
\hline Yes & $151(43.9)$ & 125 & 68 & $2.12(1.43-4.46) *$ \\
\hline \multicolumn{5}{|l|}{ HP in their family } \\
\hline Yes & $72(20.9)$ & 27 & 45 & 1 \\
\hline No & $272(79.1)$ & 187 & 85 & $1.45(1.21-3.14) *$ \\
\hline \multicolumn{5}{|l|}{ Peer/family pressure } \\
\hline Yes & $212(61.6)$ & 134 & 78 & $2.34(1.53-3.56) *$ \\
\hline No & $132(38.4)$ & 60 & 72 & 1 \\
\hline \multicolumn{5}{|c|}{$\begin{array}{l}\mathrm{SM}=\text { Self-medication, } \mathrm{NF}=\text { None formal, } \mathrm{HI}=\text { Health institution, } \mathrm{HP}=\text { Health professional, } \geq \text { Diplome } \\
=\text { parents' education diploma or above diploma; }{ }^{*} \text { significant at } \mathrm{p}-\mathrm{value}<0.05 \text {, Natural science } \\
\text { (Biology, Physics, Chemistry) Art*** (Art generalist, Music generalist, special needs, health and } \\
\text { physical education), Social science }\end{array}$} \\
\hline
\end{tabular}

\section{Prevalence, Source Of Drug And Indication Of Self- medication Practice}


Of the total respondents, 234 (68.0\%) were practice self-medication with half $(50.0 \%)$ of them were male students. Among students who practice self-medication, (33.3\%) were practice more than four times and $30.8 \%$ faced adverse drug events. More than half of students $57.7 \%$ didn't read the instruction. From the total self-medication user, $73.1 \%$ were got medication from pharmacy and $30.8 \%$ from friends (Table 2).

Table 2

Prevalence and source of drug for self-medication practice among TETC students, Amhara region, Ethiopia $2020(\mathrm{~N}=344)$

\begin{tabular}{|c|c|c|c|}
\hline Statement & Answer & Frequency & $\%$ \\
\hline \multirow[t]{2}{*}{ Do you have ever practice self-medication in your life time? } & Yes & 234 & 68.0 \\
\hline & No & 110 & 32.0 \\
\hline \multirow{4}{*}{$\begin{array}{l}\text { If your answer is yes for above question, how many times } \\
\text { practiced in your life time? }(n=234)\end{array}$} & Once & 33 & 14.1 \\
\hline & Twice & 54 & 23.1 \\
\hline & $\begin{array}{l}\text { Three } \\
\text { times }\end{array}$ & 69 & 29.5 \\
\hline & $\geq 4$ times & 78 & 33.3 \\
\hline \multirow[t]{5}{*}{ Duration of self-medication $(n=234)$} & For1 day & 57 & 24.4 \\
\hline & For 2 days & 52 & 22.2 \\
\hline & For 3 days & 45 & 19.2 \\
\hline & Four days & 33 & 14.1 \\
\hline & $\geq 5$ days & 45 & 20.1 \\
\hline \multirow[t]{2}{*}{ Do you always read the instruction? $(n=234)$} & Yes & 99 & 42.3 \\
\hline & No & 135 & 57.7 \\
\hline \multirow[t]{2}{*}{ Do you have ever face any adverse drug reaction? $(n=234)$} & Yes & 72 & 30.8 \\
\hline & No & 162 & 69.2 \\
\hline \multirow[t]{4}{*}{ Where did you get that medication? $(n=234)^{\star}$} & Pharmacy & 171 & 73.1 \\
\hline & Friends & 72 & 30.8 \\
\hline & Family & 89 & 38.0 \\
\hline & $\begin{array}{l}\text { Others } \\
\text { (specify }\end{array}$ & 27 & 11.5 \\
\hline
\end{tabular}

In this study, the most commonly cited indication of self-medication was headache (32.1\%) followed by abdominal pain (22.6\%) and common cold (19.7\%). The indication of self-medication practice among 


\section{Reasons For Self -medication Practice}

The most common reasons for choosing of self-medication reported by the respondents were disease not serous (24.4\%) followed by similarity of disease symptoms with previous illness $20.9 \%$ and easily accessibility of drugs (17.1\%) (Table 3 ).

Table 3

Reasons for self-medication practice among TETC students, Amhara region, Ethiopia $2020(n=234) *$.

\begin{tabular}{|lll|}
\hline Variable & Frequency & Percent \\
\hline Disease not serous & 57 & 24.4 \\
\hline Friends' suggestion & 30 & 12.8 \\
\hline The similarity of illness with previous illness & 49 & 20.9 \\
\hline Self-medication is cheaper & 29 & 12.4 \\
\hline Long waiting time in health service & 23 & 9.8 \\
\hline Long-distance from the health facility & 22 & 9.4 \\
\hline Do not trust health professionals & 10 & 4.3 \\
\hline Easily obtaining drugs & 40 & 17.1 \\
\hline Being embarrassed to tell about the disease & 19 & 8.1 \\
\hline The similarity of symptoms with past illness & 41 & 17.5 \\
\hline Affordability of the cost of drugs & 14 & 6.0 \\
\hline Others & 8 & 3.4 \\
\hline *Respondents have a chance to select more than one & \\
\hline
\end{tabular}

\section{Factors associated with self-medication practice among students}

Variables that were significantly associated with self-medication practices in the bivariate analysis were further examined in multivariate logistic regression. The result showed that respondents age greater than 26 were 2.47 times more likely to practice self- medication (AOR: $2.47,95 \% \mathrm{Cl}: 1.18-3.94$ ) than age between 16-20 years. Based on years of study, third year students were 3.14 times more likely to practice self-medication (AOR: 3.14, 95\% Cl: 1.94-5.79) than first year students. The odds of self- medication practice were 2.97 times higher among urban residents as compared to rural residents (AOR: $2.97,95 \% \mathrm{Cl}$ : 1.06-3.64). Accessibility of pharmacy was nearly two times (AOR: $2.12,95 \% \mathrm{Cl}$ : 1.43-4.46) more likely exposes to experience self-medication practice compared to those who had no accessibility of pharmacy. 
The odds of self-medication practice among respondents who had peer/family pressure was 2.34 times (AOR: $2.34,95 \% \mathrm{Cl}: 1.53-3.56)$ more likely to practice self-medication compared to those who hadn't peer pressure (Table 1).

\section{Discussion}

Currently, self-medication is a common practice in developed and developing countries (15). It might be lead to incorrect selection of medication, harmful drug interactions, incorrect dosage, risk of drugs dependence and abuse (16). According to this study, $68.0 \%$ of students were practiced self-medication. This finding is nearly to comparable with a study done at Addis Ababa 75.5\% (17). However, it was lower than the finding from Nigeria $92.39 \%$ (8) and South India $84.6 \%$ (18). This might be due to the presence of advanced telemedicine service and awareness about medication. On the other hand, the finding is higher than those of the studies done in Jiangsu University 47.9\% (19), West Bengal 43.24\% (20), Mekelle University $43.24 \%$ (21) and Jimma University $45.9 \%$ (22). The reason for the wide variation in the prevalence of self-medication practice might be due to the variation of social determinants of health, beliefs, and the culture of population. In this study, 30.8\% were faced adverse drug events. This study was in line with study done in North India (29.77\%) (13). However, the finding was higher than study reported from South India (5.4\%) (23).

The present study revealed that the commonest indication of self-medication practice was a headache (32.1\%) followed by abdominal pain (22.6\%). This finding was in line with the study done in Jimma Ethiopia (24). Unlike the finding of this study, the common indications for self-medication were urinary tract infection, sore throat, and diarrhoea in Nigeria (25). This may be due to the difference of prevalence of these diseases across study area. These disease also mild and self-limiting in nature and may be prevent patients from seeking physician consultation. In this study, the most commonly cited sources of drugs were pharmacy $(73.1 \%)$ followed by their family $(38.2 \%)$. This finding is similar to the study done in India (8). The main reason for practicing self-medication in this study was feeling the disease is not serious (24.4\%). This finding was similar to studies done in Jimma town (22), Iran (26) and Asella Ethiopia 24.3\% (2).

The multivariate analysis revealed that third year students were 3.14 times more likely to practice selfmedication than 1st -year students. This finding is similar to the study done in Egypt (12). The odds of self-medication practice were 2.97 times higher among urban residents as compared to rural residents. This finding was in line with the study conducted in Egypt (12). The possible explanation could be that those who lived in urban may have some awareness about the treatment and hearing drug promotion which may be encourages them to use self-medication rather than consulting the health professionals and visiting the health institutions (22). It also showed that students whose parents had more than diploma certificate education level was 2.27 times more likely to practice self-medication than whose parents unable to read and write. The possible explanation could be that those who had a diploma may have some awareness about drugs and diseases which may be push their children to practice selfmedication rather than seeking health care institution. 
Respondents who had access to the pharmacy were nearly two times more likely to practice selfmedication compared to those who hadn't. This result is consistent with those of students in China (27), India (28)' and Nigeria (29). This might be due to most of the private pharmacies sold medication without a prescription of health professionals. The odds of self-medication practice among respondents who had peer/family pressure was 2.34 times more likely to practice self-medication as compared to those who hadn't. The current result is consistent with those of studies carried out in China (27) and Uganda (30). The possible explanation may be that friends/families were common sources of information about medication in developing countries like Ethiopia.

\section{Limitation}

The study has some limitations that should be taken into account while interpreting the results. As the study is cross-sectional and depends on self-reported assessment, under-reporting is more likely to occur. This study is limited to self-medication practices only not include attitude and awareness of the participants.

\section{Conclusion}

The result of the study revealed that two-thirds of the study participants practiced self-medication. Being from an urban area, having access to private pharmacy, increase year of study, parents' education level and having peer/family pressure are significant factors for self-medication.

\section{Abbreviations And Acronyms}

AOR - Adjusted odds ratio

COR - Crud odds ratio

ETB - Ethiopian birr

OTC - Over the counter

SPSS - Statistical Package for Social Sciences

\section{Declarations}

\section{Ethics approval and consent to participate}

This study was approved by the ethical committee of the school of pharmacy, the University of Gondar with an approval number of SoP-318/2012. Informed verbal, as well as written consent was obtained from study participants prior to the data collection, and the purpose of the study was explained to the respondents in advance. The information collected from respondents was kept confidential. 


\section{Conflict of interest}

The authors declare that they have no conflict of interests.

\section{Publication consent}

Not applicable

\section{Funding}

Not applicable

\section{Availability of data and materials}

The data sets supporting the finding of this study can be obtained from the corresponding author upon a formal request.

\section{Author contribution}

ABM contributed to design the study, write up of the final research, data interpretation, data analysis, final manuscript preparation and supervision of the study. MTT and MG participated in data analysis, data interpretation and. TAB contributed to writing up the final research, data interpretation and manuscript preparation. All authors read and approved the final manuscript.

\section{Acknowledgment}

The authors would like to acknowledge the Dean of each teachers' education training college who gave permission for the data collection and we want to acknowledge the registrar, teachers, and students of the college for their voluntary participation.

\section{References}

1. Organization WH. Responsible self-care and self-medication; A worldwide review of consumers' survey; the World Self-Medication Industry. 2010.

2. Bekele SA, Argaw MD, Yalew AW. Magnitude and factors associated with self-medication practices among university students: the case of Arsi University, College of Health Science, Asella, Ethiopia: cross-sectional survey based study. Open Access Library Journal. 2016;3(6):1-15.

3. Karimy M, Rezaee-Momtaz M, Tavousi M, Montazeri A, Araban M. Risk factors associated with selfmedication among women in Iran. BMC Public Health. 2019;19(1):1033-40.

4. Lei $X$, Jiang H, Liu C, Ferrier A, Mugavin J. Self-medication practice and associated factors among residents in Wuhan, China. Int J Environ Res Public Health. 2018;15(1):68-78.

5. Gore P, Madhavan S. Consumers' preference and willingness to pay for pharmacist counselling for non-prescription medicines. J Clin Pharm Ther. 1994;19(1):17-25. 
6. Shokrzadeh M, Hoseinpoor R, Jafari D, Jalilian J, Shayeste Y. Self-medication practice and associated factors among adults in Gorgan, north of Iran. Iranian Journal of Health Sciences. 2019;7(2):29-38.

7. Lukovic JA, Miletic V, Pekmezovic T, Trajkovic G, Ratkovic N, Aleksic D, et al. Self-medication practices and risk factors for self-medication among medical students in Belgrade, Serbia. PloS one. 2014;9(12):1-14.

8. Johnson D, Sekhar HS, Alex T, Kumaraswamy M, Chopra RS. Self medication practice among medical, pharmacy and nursing students. Int J Pharm Pharm Sci. 2016;8(7):1-6.

9. Xiao X, Wu Z-C, Chou K-C. A multi-label classifier for predicting the subcellular localization of gramnegative bacterial proteins with both single and multiple sites. PloS one. 2011;6(6):1-10.

10. Garofalo L, Di Giuseppe G, Angelillo IF. Self-medication practices among parents in Italy. BioMed research international. 2015;2015:1-9.

11. Arrais PSD, Fernandes MEP, Pizzol TdSD, Ramos LR, Mengue SS, Luiza VL, et al. Prevalence of selfmedication in Brazil and associated factors. Revista de saude publica. 2016;50(13):1-10.

12. Helal R, Abou-ElWafa H. Self-medication in university students from the city of Mansoura. Egypt Journal of environmental public health. 2017;2017:1-7.

13. Parakh R, Sharma N, Kothari K, Parakh R, Parakh P. Selfmedication practice among engineering students in an engineering college in North India. J Phytopharm. 2013;2:30-6.

14. Kassie AD, Bifftu BB, Mekonnen HS. Self-medication practice and associated factors among adult household members in Meket district, Northeast Ethiopia, 2017. BMC Pharmacology Toxicology. 2018;19(1):15-23.

15. Biset Ayalew M. Self-medication practice in Ethiopia: a systematic review. 2017;11(3):401-13.

16. Mamo S, Ayele Y, Dechasa M. Self-medication practices among community of harar city and its surroundings, Eastern Ethiopia. Journal of pharmaceutics. 2018;2018:1-6.

17. Shafie M, Eyasu M, Muzeyin K, Worku Y, Martin-Aragon S. Prevalence and determinants of selfmedication practice among selected households in Addis Ababa community. PloS one. 2018;13(3):1-20.

18. Kumar N, Kanchan T, Unnikrishnan B, Rekha T, Mithra P, Kulkarni V, et al. Perceptions and practices of self-medication among medical students in coastal South India. PloS one. 2013;8(8):1-5.

19. Zhu X, Pan H, Yang Z, Cui B, Zhang D, Ba-Thein W. Self-medication practices with antibiotics among Chinese university students. Public Health. 2016;130:78-83.

20. Banerjee I, Bhadury T. Self-medication practice among undergraduate medical students in a tertiary care medical college, West Bengal. Journal of postgraduate medicine. 2012;58(2):127-31.

21. Gutema GB, Gadisa DA, Kidanemariam ZA, Berhe DF, Berhe AH, Hadera MG, et al. Self-medication practices among health sciences students: the case of Mekelle University. Journal of Applied Pharmaceutical Science. 2011;1(10):183-9. 
22. Ararsa A, Bekele A. Assessment of self-medication practice and drug storage on private pharmacy clients in Jimma town, Oromia, south West Ethiopia. AJPS. 2015;1(1):20-32.

23. Badiger S, Kundapur R, Jain A, Kumar A, Pattanshetty S, Thakolkaran N, et al. Self-medication patterns among medical students in South India. The Australasian medical journal. 2012;5(4):21720.

24. Shehnaz SI, Agarwal AK, Khan N. A systematic review of self-medication practices among adolescents. J Adolesc Health. 2014;55(4):467-83.

25. Osemene K, Lamikanra A. A study of the prevalence of self-medication practice among university students in Southwestern Nigeria. Tropical Journal of Pharmaceutical Research. 2012;11(4):683-9.

26. Jaleta A, Tesema S, Yimam B. Self-medication practice in sire town, West Ethiopia: a cross-sectional study. Cukurova Med J. 2016;41(3):447-52.

27. Wen Y, Lieber E, Wan D, Hong Y, Group NCHSPT. A qualitative study about self-medication in the community among market vendors in Fuzhou, China. Health Soc Care Commun. 2011;19(5):504-13.

28. Divya M, Bharatesh S, Vasudeva G, Varalakshmi C. Self-Medication Among Adults in Urban Udupi Taluk, Southern India. International Journal of Medicine Public Health. 2016;6(3):126-9.

29. Abdulraheem I, Adegboye A, Fatiregun A. Self-medication with antibiotics: empirical evidence from a Nigerian rural population. Journal of Pharmaceutical Research International. 2016:1-13.

30. Ocan M, Bwanga F, Bbosa GS, Bagenda D, Waako P, Ogwal-Okeng J, et al. Patterns and predictors of self-medication in northern Uganda. PloS one. 2014;9(3):1-7.

\section{Figures}




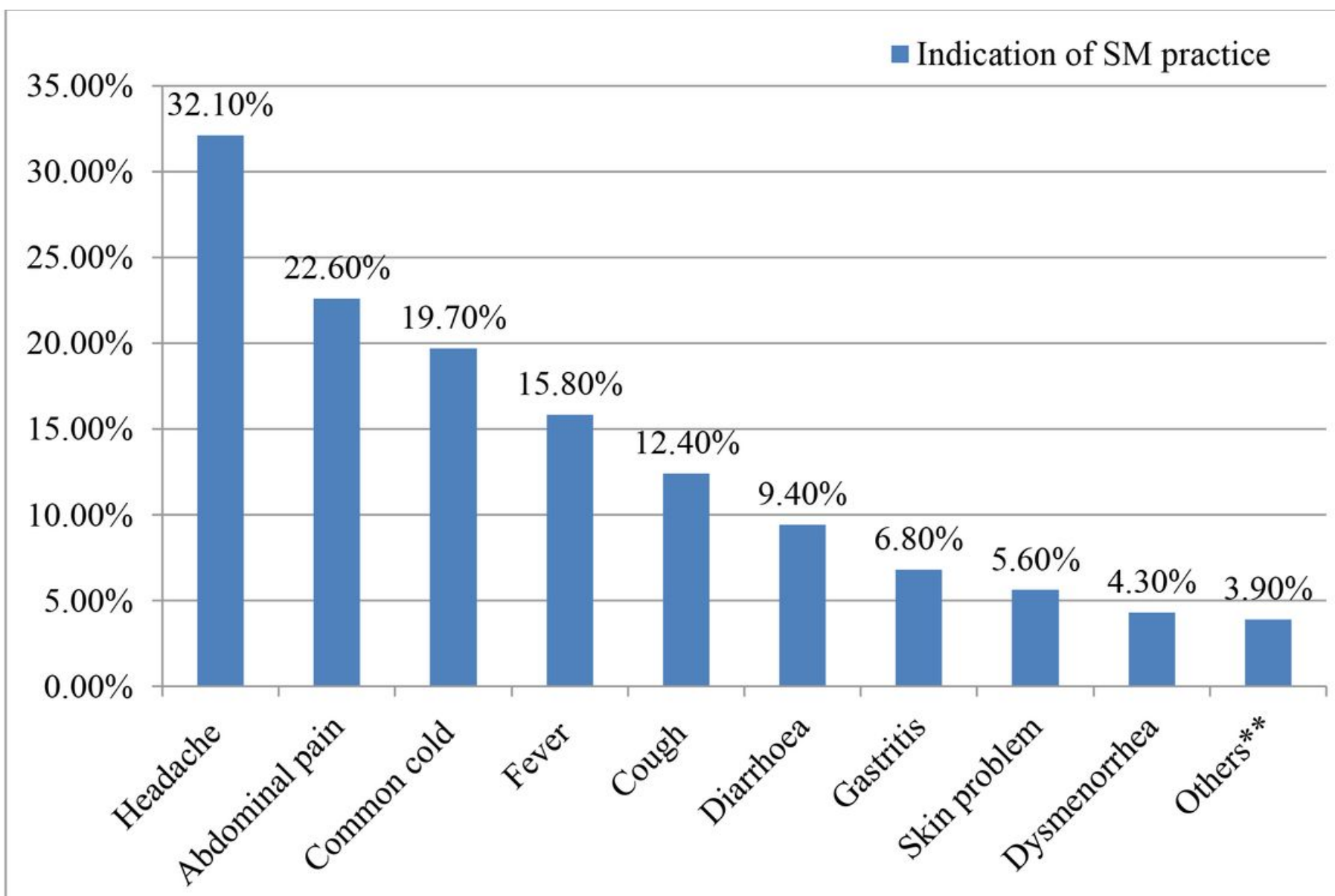

Fig 1: Indication of drugs for self-medication practice among students, Amhara region, Ethiopia $2020(\mathrm{n}=234)^{*}$

*Posible more than one choice ** Nausea/vomiting, loss of appetite, contraceptive

\section{Figure 1}

*Posible more than one choice ** Nausea/vomiting, loss of appetite, contraceptive

\section{Supplementary Files}

This is a list of supplementary files associated with this preprint. Click to download.

- Datacollectiontool.docx

- STROBEchecklistcrosssectional.doc 